doubt, from the fact that specialists have contributed material about which they are particularly enthusiastic. In the aggregate, that has produced a volume which will be of great value both to the student of phycology and to those whose interests in the subject are of a more general character. LILY NEWTON

\section{AN AMERICAN TEXT-BOOK OF ZOOLOGY}

Anatomy of the Chordates

By Prof. Charles K. Weichert. (McGraw-Hill Publications in the Zoological Sciences.) Pp. vii+921. (London: McGraw-Hill Publishing Co., Ltd., 1951.) $68 s$.

DROF. C. K. WEICHERT is professor of zoology $P$ in the University of Cincinnati, Ohio, and this book is written primarily for American students 'majoring' in zoology. Only four representative animals are dealt with in detail : Petromyzon, a dogfish, the salamander 'mud puppy' (Necturus maculosus), and the cat. The consideration of the four selected types occupies fewer than a hundred and fifty of the total of nine hundred-odd pages of letterpress. This disproportionate lack of emphasis on gross anatomy may prove a little horrifying to those who have been nurtured on the broader morphological fare that characterizes the zoology courses in British universities. But if we deprecate that so much has been left out, we cannot but admire much of the material that Prof. Weichert has been at such pains carefully to collate, correlate and put in.

The book is divided into three principal sections. Part 1 is devoted to classification, natural history and development. Part 3 deals with the four animals mentioned above. The second part of the volume deals extensively with the organ systems of vertebrates, and is probably the finest account of its kind available in any text-book of zoology. The integumentary, digestive, respiratory, circulatory, endocrine, reproductive and other systems-and the receptor organs-are all treated from a comparative point of view, and there is a pleasing emphasis on function, as well as structure, throughout the series. Numerous excellent, clearly labelled diagrams illustrate the text.

Another admirable feature of the volume is its passing treatment of the biology of man wherever appropriate. It has to be confessed that many students graduate with an honours degree in zoology yet still possess only the sketchiest knowledge of the biology of themselves. Certainly this charge could not be laid to Prof. Weichert's students ; in fact, the inclusion of the diagram illustrating McBurney's point (for the location of the human appendix) and one or two other minor matters could lead, perhaps, to the conclusion that he has carried his zeal in this direction a trifle too far. A possibly unfortunate trace of provincialism, too, occurs here and there. For example, in a text unburdened by references to original research we read that "the experiments of Prof. Carl Moore and his co-workers have definitely established that the scrotum serves as a temperature regulator". This being so, it would have been gracious also to have mentioned the name of the distinguished foreigner whose pioneer work first made it clear that such was the case and provided a basis for all subsequent work on the subject.
"Anatomy of the Chordates" should prove most valuable for collateral reading in Great Britain, for it contains much information that is not usually given in British text-books of zoology. In production, the book epitomizes the high standard that we have come to expect from the McGraw-Hill Company. It is a pity that the high price of North American publications (68s. in this case) will probably preclude most British students from personal ownership.

A. J. MarshaLI

\section{POLYZOA AND THE AGE OF THE CRAGS}

The Pliocene- Bryozoa of the Low Countries and their Bearing on the Marine Stratigraphy of the North Sea Region

By Robert Lagaaij. Pp. $233+26$ plates. (Maastricht : Uitgevers-Mij Ernest Van Aelst, 1952.)

HIS work originated in a study of the Bryozoa (Polyzoa) obtained from borings in Holland; but it was extended in an attempt to use them for correlating certain horizons of the Pliocene in the North Sea area. It consequently also involved the investigation of British and Belgian material of similar age, that from England being from the Coralline and Waltonian Crags of Suffolk and Essex. For such a stratigraphical correlation and discussion to be of any value, the identifications of the species must be critically made. Dr. Robert Lagaaij has therefore re-examined much of the material, now in the British Museum (Natural History), described in 1859 by G. Busk in his classic "Monograph of the Fossil Polyzoa of the Crag", and in addition he has made extensive use for purposes of comparison of the magnificent collection of Recent Polyzoa there. Thus the systematics have been very carefully worked out, and zoologists and palæontologists studying the group will find much of value to them in the results. Both Cheilostomata and Cyclostomata are dealt with, the former contributing the major part of the fauna. The numerous photographs and admirable text-figure drawings fully illustrate the text.

For British palæontologists the Polyzoan fauna described from the Waltonian is of some interest, though it has to be searched for in the section on systematics. For that horizon the author has confined his attention to the encrusting forms (with one exception) so as to be sure he was considering indigenous specimens and not those derived from the Coralline Crag.

With the systematics securely based, the stratigraphical results deduced from an analysis of the Polyzoan faunas can be accepted with confidence. They concern particularly the Scaldisian-Poederlian deposits of Belgium and Holland and the Coralline and Waltonian Crags of East Anglia, but also deal with the Diestian. The fauna of the Lower Diestian is held to be older than that of the Coralline Crag and to bear strong Miocene affinities. The Scaldisian of Antwerp and the Netherlands, with a high percentage of Polyzor in common with the Gedgravian (Coralline Crag), can clearly be correlated with the last named. The author supports the suggestion that the Poederlian is a transgressive facies of the Lower Amstelian, and correlates it with the Waltonian of Essex, in which the first 'colder' Polyzoa appear : these are taken as the equivalents of the Calabrian 